\title{
Establishing a library publications
}

\section{program}

\author{
By Rachael Naismith \\ Reference Librarian and Publications Coordinator \\ Carnegie-Mellon University
}

\section{How to orchestrate the publication of your library's guides} and brochures.

\begin{abstract}
$\mathbf{T}$ publications.

True or false? As soon as you finish a handout you always acquire an absolutely essential encyclopedia and have to type the whole thing over again.

True or false? Everyone in your library writes in a completely unique style, and all your guides look totally different, and that's just the way life is.
\end{abstract}

The answer to all of the above is: not necessarily. This article describes a successful attempt to manage the production of high-quality publications in a painless and even enjoyable way.

Carnegie-Mellon University Libraries' Publications Program was created in the fall of 1983. The primary purpose of a formalized program was "to ensure a uniform approach to writing, editing, producing, and distributing several types of public-use documents...to reinforce the image of the Libraries as a dynamic, professional organization within an equally dynamic university community." I had recently joined the reference staff, and was asked by Tom Michalak, the director, to assume the role of Publications Coordinator.

With a few exceptions ${ }^{2}$ recent literature on the

${ }^{1}$ Carnegie-Mellon University Libraries, Publications Guidelines (Pittsburgh: Carnegie-Mellon University, 1983).

${ }^{2}$ William J. Jackson, "The User-Friendly Li- subject of library publications is nonexistent. I therefore turned to the resources at hand in my attempt to structure the program. These can be seen as falling into two categories-technical resources and people resources.

Technical resources. Not every student at Carnegie-Mellon University owns a computer, but every student has access to one on campus. Students are as likely to ask the reference librarian for the use of a PC as they are for a piece of paper. The technical resources available at CMU include a number of mainframe computers which offer strong and flexible text editing and text formatting programs called, respectively, EMACS and SCRIBE. The SCRIBE program uses commands that are entered with the text. These commands specify the typeface, margins, tabs, and so on that the program should implement. Documents can be typed into files, edited, formatted on the University DEC-20s and produced on a Xerox X9700 printer. ${ }^{3}$ Documents can also be typed and edited

brary Guide," CઐRL News 45 (October 1984):468-71.

${ }^{3}$ For a more detailed description of the Libraries' use of central computing facilities, including electronic mail, see Thomas J. Michalak, “The Application of Centralized Text Editing and Electronic Mail Systems in Libraries: The CMU Experience," Library Hi Tech 1 (Spring 1984):35-41. 
on an IBM PC microcomputer and uploaded to the mainframe for formatting.

People resources. The "people resources" available to me included a group of creative librarians who are subject specialists, all of whom had written handouts and guides in their subject areas. A number of service and policy announcements already existed. Furthermore, the library director

\section{Every aspect of production} is accomplished within the library.

saw the development of the program as a high priority, and was ready to allocate time and money as needed. An Editorial Board was appointed, consisting of library professional and non-professional staff members from both public and technical services. In addition to the resources present within the library, the university was replete with expert consultants, from computer analysts to public relations personnel and an English department whose programs focus on rhetoric and written composition.

\section{Structuring the program}

A Publications Ad Hoc Committee was established 1) to write publications guidelines to be used by authors and editors and 2) to decide upon an attractive publication design. The first steps taken by the Committee can again be seen in terms of technical aspects and people aspects.

Technical aspects. The Publications Committee worked out the document design in a way that would take advantage of SCRIBE options. After consultations with the University Computation Center, a sans serif typeface font, Univers 10 , was chosen and a SCRIBE format was selected. The format specified such details as use of bold type or italics, amount of space following a subheading,

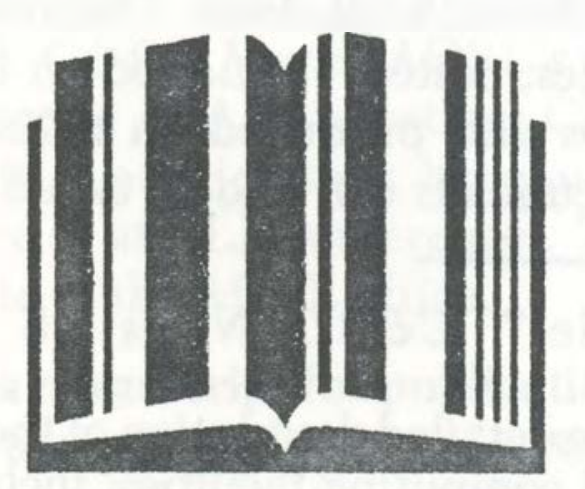

\section{CMU Libraries}

and placement of the author's name.

A graphic design student was commissioned to design the library logo-a book, the pages of which resemble a bar code. This simple linear design was selected in part because of its suitability for digitizing. This allows the image to be read by the computer and translated into the printed equivalent on a Xerox laser printer, thus enabling CMU Libraries to produce the final document in one step, without photostatting, pasting, or waiting for campus printers to complete the job.

People aspects. The usefulness of EMACS and SCRIBE in the production of the documents seemed obvious. The delineation of an editing mechanism seemed less so. After a lot of brainstorming, supplemented by consultations with other librarians, with faculty members in the English Department, and with the Chicago Manual of Style, the Publications Committee composed the eleven-page Publications Guidelines. Library professionals can obtain copies of the guidelines by writing to Rachael Naismith, Publications Coordinator, Carnegie-Mellon University Libraries, Pittsburgh, PA 15207.

\section{Content of the Guidelines}

The guidelines tell authors (almost) everything they need to know about document style. The guidelines begin by describing the need for library publications. Publications overseen by the Editorial Board are classified into these types: bibliographies, "how to" guides, service guides, special publications (e.g. a library handbook), online tutorials and help systems. Bibliographies are generally annotated and focus on specific subject areas. "How to" guides on the other hand are pathfinders or "point of use" handouts. They serve as narrative guides to research in a subject area, or as guides to the use of complex reference sources, such as citation indexes. Service guides are brief descriptions of library services, such as interlibrary loan. Projects such as a library handbook or brochure fall into the category of special publications. Finally, online tutorial and help systems are being printed. These will require editorial decisions similar to print publications, and yet have specific contingencies related to their non-print nature.

The Publications Guidelines address document content, discussing the introduction to the handout, the arrangement of sections within the body, and so on. The guidelines are not so specific that individual style is crimped. They do, however, provide authors with a set of standards which can be extremely helpful in document design.

The guidelines also review CMU Libraries' editorial procedure. They define the roles and responsibilities of the Publications Coordinator, the Editorial Board, and the authors. The authors, subject specialists, and other members of the library staff who are experienced in an area of library resources are responsible for: 
On Microfilm . . f from Research Publications

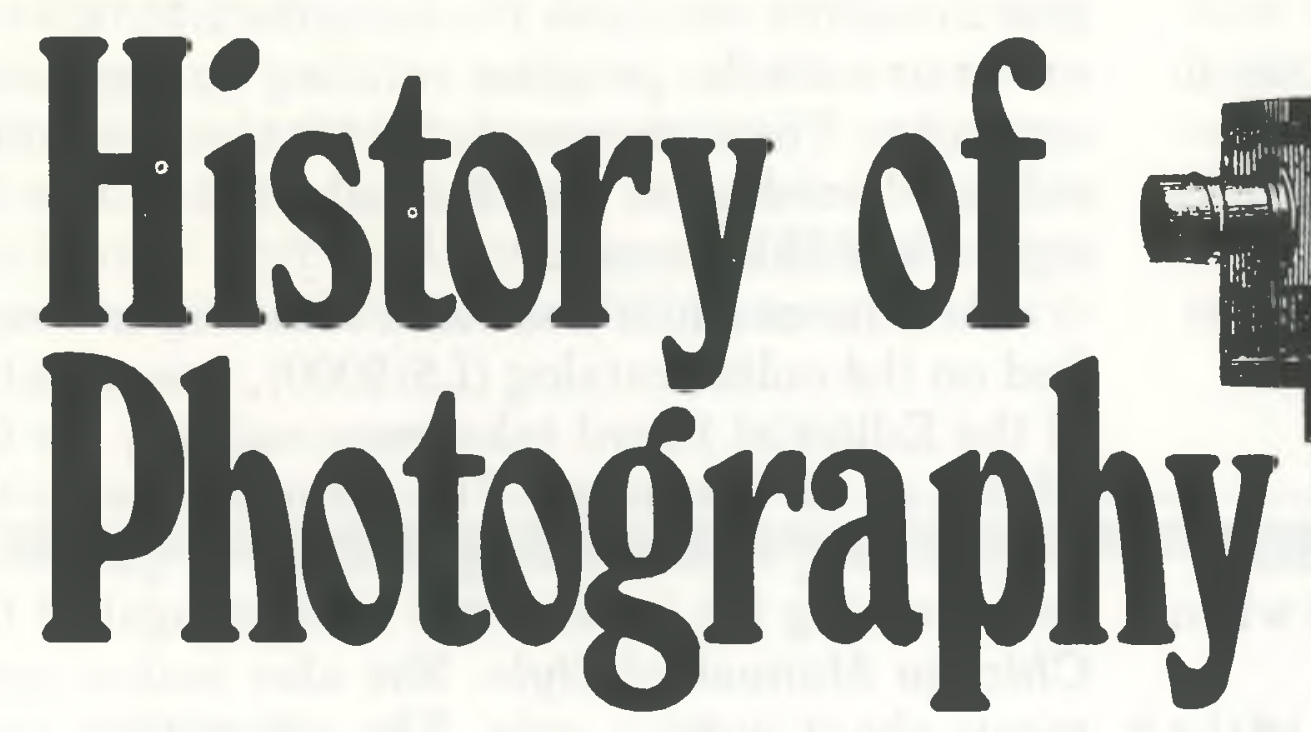

From its beauty as an art form to its impact as a visual information medium, the history of photography is documented in this collection from Research Publications.

Compiled primarily from the holdings of the International Museum of Photography at the George Eastman House, this exceptionally informative source presents over 2,100 monographs and periodicals published between 1830 and the early 1900s. The year-by-year development of photographic style and technique is traced through the works and personal accounts of well-known photographers.

\section{Finest Quality Detail}

The subtle shadings and delicate contrasts of the photographs are captured in this collection through the utilization of ultrasensitive equipment, various development emulsions, and innovative microfilm processing techniques. A bibliographic guide is provided with each order.

For only $\$ 16,500$. this exceptional, comprehensive 489-reel collection can become a permanent picture in your resource album.

Prices slightly higher outside the U.S. and Canada.

To order, or for more information on History of Photography, call or write:

Research Publications 12 Lunar Drive/Drawer AB

Woodbridge, CT 06525 (203) 397-2600

TWX: 710-465-6345

FAX: 203-397-3893
Outside North and South America: P.O. Box 45

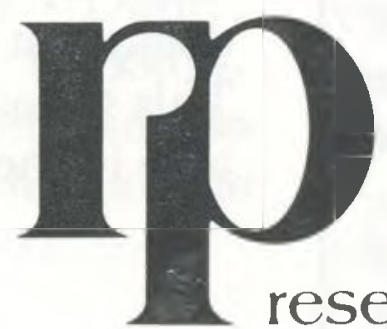
Reading, RG1 8HF England TEL: 0734-583247 TELEX: 848336 NADL G 
-providing accurate content, including correct citations, call numbers, and book locations;

- giving the manuscript to the Editorial Board within a reasonable amount of time and in a readable format-preferably on a diskette or as an EMACS file;

-adhering to these Publications Guidelines in the areas of procedure, content, and style.

The Publication Coordinator's responsibilities include:

- chairing the Editorial Board;

- overseeing publications policies;

- coordinating production.

The Editorial Board is responsible for:

- editing publications for format and content;

- meeting with authors to suggest changes when needed;

- commissioning publications to fill gaps in the publications collection.

The last section of the guidelines deals with citation format. Authors are asked to follow the Chicago Manual of Style, unless they prefer a style specific to the discipline discussed in the handout.

\section{The editorial procedure}

The Publications Committee was disbanded when the publications guidelines and document design were completed. The Editorial Board took over and met weekly for several months, editing the core of handouts, mostly subject bibliographies, that already existed in typewritten form. The first handout that was edited, input on EMACS, and produced was a bibliography on artificial intelligence, a subject close to the hearts of CMU researchers. To date, sixteen guides have been produced and twelve others are in progress. Subject areas covered include census data, cognitive psychology, computer graphics, grants, musical theatre, and survival skills for the artist.

\section{A special thanks to library newsletter editors}

Many of the announcements that appear in $C \triangleleft R L$ News have come to my attention in newsletters published by various academic libraries. I wish to thank all of you for keeping $C \mho R L$ News on the mailing list, and please be assured, I do read every one of them. I also appreciate the cartoons and humorous comments that enliven some of them (the University of Arizona and the University of California, Davis, among others).

If your library has a newsletter that contains notices of appointments, acquisitions, grants, awards, workshops, or other library activities that might be worth a mention in C $b R L N e w s$, please add us to your mailing list. Send issues to: Editor, C $\triangleleft R L$ News, 50 E. Huron St., Chicago, IL 60611-2795.-George M. Eberhart, Editor.
The process of editing and production occurs in the following way. The author writes a handout for use in library instruction or perhaps written specifically for use in the Reference Area. The author or a work-study student enters the handout into a machine-readable file using the EMACS text editor or a similar program running on a personal computer. The author sends the file to me as Publications Coordinator and it is adapted to the designed SCRIBE format.

After the citations and book locations are verified on the online catalog (LS/2000), one member of the Editorial Board takes responsibility for the editing of the document. The editor marks up the copy, noting format and grammatical questions, and checking the form of the citation against the Chicago Manual of Style. She also makes comments about writing style. The editor then gives copies of the handout, complete with corrections, to the Editorial Board.

The Board reviews one or two handouts at a meeting, with the editor of each handout leading a discussion of her suggestions. Frequently, other members of the Editorial Board will pick up problems which the person responsible for the handout missed. The editor meets with the author and explains the suggestions of the Editorial Board. The author accepts or rejects the ideas, and the resulting document is usually the product of compromise.

A student assistant then re-edits the document, making the citation or content changes. The SCRIBE commands which produce the masthead (including the logo) are added. The document is produced on the Xerox printer and is shown to the author for final approval. The document is then copied on the libraries' copiers. Copies of the handout are displayed in Reference, Circulation, or whatever area is helpful to the library user. Copies are also sent to Project LOEX in Michigan, for lending to other libraries. Finally, the document file is "migrated" offline, easily available for updating and reproduction.

\section{Beyond the printed page}

A recent development in the publications program has been the loading of the existing computer files into an information subsystem of the online catalog. When a student or professor calls up this subsystem, she will be presented with a menu of options, including library hours, announcements, online catalog tips, and library publications. Upon selecting "Library Publications," the individual will be provided with a list of the available publications. By choosing one, the person can call up the document and page through it screen by screen. This system is now being tested and will be available in the spring of 1985 .

\section{Conclusion}

The result of our efforts has been an increasingly diverse selection of attractive library publications 
which are well-written and well-edited. The Libraries are making good use of the text processing resources available at Carnegie-Mellon University, and yet we are not spending a great deal of money on our products. We are using our own copiers and have work-study students doing the online editing, the copying, and the collating. Publications are printed on relatively inexpensive ivory bond paper. Every aspect of production is accomplished within the library. Best of all, revisions of publications can be accomplished in minutes. While many universi- ties do not have the centralized computer facilities that we have available at CMU, microcomputers do present alternatives for text editing. Aside from the technical points to consider, any library can benefit from the establishment of an editing procedure in writing. Often library publications are the byproduct of other library activities, such as a BI session or a detailed assignment on census materials. If a publication mechanism exists, even handouts which arise from a hasty assignment or classroom presentation can be of high quality.

\section{ACRL list of materials available}

\section{A complete checklist of ACRL publications in print.}

\begin{abstract}
$S^{2}$ are free. Other publications are priced as listed. ALA members are eligible for a $10 \%$ discount on all ACRL publications. ACRL members receive an additional discount of $20-30 \%$ as noted. To receive the discount, give your membership number and deduct the discount when preparing your orders.

Institutions may order on account, plus postage and handling. Individuals may order on account, plus postage and handling, except that prepayment should accompany individuals' orders of $\$ 15$ or less. No postage and handling charges are added to prepaid orders (check, money order, credit card). All prices are payable in U.S. funds. All materials sent outside the U.S. will be mailed surface rates unless airmail postage is prepaid.

Quantity discounts are available when five or more copies of the same title are ordered to be shipped to the same address. Inquire for prices on specific titles.

Send orders to: Publications Dept., ACRL/ALA, 50 E. Huron St., Chicago, IL 606112795; (312) 944-6780. ACRL publications can also be ordered from ALA Publishing Services at the same address.
\end{abstract}

\section{Standards and guidelines}

- Standards for University Libraries. (CむRL
News, April 1979). ACRL/ARL.

- Standards for College Libraries. (C\&RL News, October 1975).

- The Use and Effectiveness of the 1975 Standards for College Libraries (1981). Larry Hardesty, Chair, Ad Hoc Committee on Standards and Guidelines, College Libraries Section, ACRL.

- An Evaluative Checklist for Reviewing a College Library Program, Based on the 1975 Standards for College Libraries. (CむRL News, November 1979).

- Guidelines for Two-Year College Learning Resources Programs. (C\&RL News, January and February 1982). ACRL/AECT.

- Statement on Quantitative Standards for Two-Year Learning Resources Programs (1979). (Draft available in C $\triangleleft R L$ News, March 1979).

- Guidelines for Bibliographic Instruction in Academic Libraries. (C\&RL News, April 1977).

-Access Policy Guidelines. (CむRL News, November 1975).

- Guidelines for Branch Libraries in Colleges and Universities. (CむRL News, October 1975).

- Guidelines for Extended Campus Library Services. (C\&RL News, March 1982).

- The Mission of an Undergraduate Library (Model Statement). (CむRL News, November 1979). 